\title{
ENTRE SAMBAS, CONCEITOS E POLÍTICAS: CULTURAS POPULARES EM DISPUTA
}

\author{
Marcus Bernardes ${ }^{1}$
}

\begin{abstract}
Resumo: O presente ensaio propõe o debate acerca das concepções de cultura popular e seu entrelaçamento com as noções de folclore, povo e patrimônio, no intuito de perceber as implicações políticas destes usos. A criação da ideia de folclore é desenvolvida concomitantemente e influenciada pelo pensamento das Ciências Sociais no século XIX. A questão inicial dos folcloristas, no sentido de registro das manifestações da cultura popular, está ligada ao projeto moderno dos governos democráticos liberais de manter as concepções de povo e nacionalidade dentro do capitalismo. Para tanto, no caso brasileiro, destaco a influência do pensamento de Mário de Andrade nas relações estabelecidas entre o Estado e as culturas populares. E também, a partir de um estudo de caso sobre a patrimonialização do Samba de Roda do Recôncavo Baiano, analiso as implicações políticas atuais devedoras ainda dos teóricos folcloristas.
\end{abstract}

Palavras-Chaves: Culturas Populares. Folclore. Patrimônio Cultural.

\section{ENTRE SAMBAS, CONCEPTOS Y POLÍTICAS: CULTURAS POPULARES EM DISPUTA}

Resumen: El presente ensayo propone el debate acerca de las concepciones de cultura popular y su entrelazamiento con las nociones de folclore, pueblo y patrimonio, con el fin de percibir las implicaciones políticas de estos usos. La creación de la idea de folclore se desarrolla concomitantemente e influenciada por el pensamiento de las Ciencias Sociales en el siglo XIX. La cuestión inicial de los folcloristas, en el sentido de registro de las manifestaciones de la cultura popular, está ligada al proyecto moderno de los gobiernos democráticos liberales de mantener las concepciones de pueblo y nacionalidad dentro del capitalismo. Para ello, en el caso brasileño, destaco la influencia del pensamiento de Mário de Andrade en las relaciones establecidas entre el Estado y las culturas populares. Y también, a partir de un estudio de caso sobre la patrimonialización del Samba de Roda del Recôncavo Baiano, yo analisis las implicaciones políticas actuales deudoras aún de los teóricos folcloristas.

Palabras Claves: Culturas Populares. Folclore. Patrimonio Cultural.

\footnotetext{
${ }^{1}$ Mestre em Antropologia Social pela Universidade Federal de Goiás. Professor de Ciências Sociais do Centro Universitário UniFG. E-mail: marcusbernardes@outlook.com.br.
} 


\section{Introdução}

Nas perspectivas da Sociologia da Cultura e da Antropologia, a palavra cultura adjetivada de popular traz uma série de complexidades analíticas. Existem diferenças significativas das concepções de cultura popular para folcloristas e cientistas sociais. Divergências tanto de projeto de empreendimento científico quanto ao nível de conceituação. O estudo da cultura popular no Brasil de fins do século XIX e ao longo do XX, esteve atrelado à questão da identidade nacional, abordada inicialmente pelos folcloristas. Na Europa do século XIX, a valorização do saber popular estava imbricada com as teorias positivistas da época. Assim o estudo da cultura popular também se confundia com o estudo do homem primitivo, do exótico, dos traços culturais sobreviventes, daqueles povos não inteiramente afetados pela industrialização e eram os antropólogos evolucionistas, os românticos e os folcloristas que principiaram tais observações.

Tais digressões históricas sobre o conceito de cultura popular serão articuladas neste ensaio, tomando por base, dimensões específicas no qual o Estado brasileiro se relaciona com as culturas populares circunscritas ao seu território. Em função deste universo de análise extremamente difuso, procedo com algumas delimitações. Apresento uma breve exposição histórica sobre os conceitos de Cultura e Civilização, debate este fundamental para compreendermos os usos políticos e científicos das noções de folclore e culturas populares. Em seguida, analiso a influência de um intelectual brasileiro nas políticas culturais do Brasil: Mário de Andrade. A música possui uma centralidade nos seus estudos, enfatizo aqui sua obra Ensaio sobre a Música Brasileira. Continuando no universo musical, delimito uma vez mais para um estudo de caso sobre o Samba de Roda do Recôncavo Baiano. Como tal musicalidade passou por um processo recente de patrimonialização, a partir dela é possível compreender as implicações práticas de como o Estado, através dos seus intelectuais e agentes, lidam com as culturas populares.

O conceito de civilização expressa a consciência que o Ocidente tem de si mesmo. Um projeto imperialista de criação de um modelo a ser seguido. Contudo, não é um conceito que possui significação única para os diferentes países europeus. Para a Inglaterra e França, o termo "civilização" remete a uma noção de progresso para a humanidade; para os alemães, Zivilisation é um valor secundário e superficial, sendo a "Cultura" (Kultur) o conceito que 
expressaria melhor o orgulho das realizações nacionais (ELIAS; 2011). O conceito alemão de Kultur remete ao particularismo histórico, a identidade de grupos e diferenças nacionais, por isso o conceito se expandiu a partir de pesquisas antropológicas. Na Alemanha, o conceito de cultura é pensado e desenvolvido por uma intelligentsia (intelectuais burgueses) que não tinha influência nas decisões políticas, no sentido de governabilidade.

Na metade do século XVIII, os intelectuais burgueses alemães eram uma elite diante da população em geral, mas uma segunda classe para a aristocracia cortesã. Se na França, Civilisation pode ser entendida como a autoimagem do seu país, Kultur era a autoimagem da classe intelectual alemã, responsável por difundir uma nova língua culta, nas figuras do clérigo e do professor. Nesse sentido, na Alemanha, dois conceitos vão se desenvolvendo assimilando características distintas, enquanto Kultur remete a profundeza, honestidade, autenticidade, Zivilization se caracteriza pela superficialidade, falsidade, na ordem da aparência. Elias (2011) identifica o processo no qual esta antítese social torna-se paulatinamente nacional. Na França, a burguesia não se diferenciava tanto da aristocracia, setores importantes da burguesia foram absorvidos pela aristocracia de corte no século XVIII. Depois da Revolução Francesa os valores aristocráticos (absorvidos pela classe média) tornam-se valores nacionais. Já na Alemanha, onde ocorreu um processo de diferenciação entre burguesia e aristocracia, com a ascensão da classe média alemã, suas características sociais específicas vão se transformando em características nacionais.

O conceito francês de civilisation, exatamente como o conceito alemão correspondente de Kultur, emergiu nesse movimento de oposição na segunda metade do século XVIII. Seu processo de formação, função e significado foi tão diferente dos implícitos no conceito alemão como as circunstâncias e costumes da classe média nos dois países (ELIAS, 2011, p. 51).

Dessa forma, é nesse processo de construção de uma identidade nacional que se vincula o interesse dos intelectuais pelos costumes do povo. Segundo Burke (2010) este interesse possuía razões estéticas e políticas. Estéticas por sua revolta contra a arte vigente; o romantismo no campo artístico buscava uma maior autonomia de criação individual. As razões políticas vinculam-se a própria ideia de nação, construída a partir de referenciais do que estes intelectuais (românticos, folcloristas) acreditavam 
ser efetivamente do povo. Os românticos são responsáveis pela criação da ideia de uma cultura popular anônima, autêntica, que refletiria a alma nacional; enquanto os folcloristas foram os continuadores desse processo. Nos séculos XVII e XVIII, não existia uma separação nítida entre uma cultura erudita e outra popular, ambas se entrelaçavam caso fosse possível falar em duas realidades em termos antagônicos. Entretanto, o processo de interação entre elite e povo não era simétrico, "a gente culta não associava baladas, livros populares e festas à gente comum, precisamente porque também participava, ela mesma, dessas formas de cultura" (BURKE, 2010, p. 55), mas o $p o v o^{2}$ não compartilhava do universo das elites. Só então no século XIX, que as tradições populares são descobertas pelos intelectuais.

A busca de tradições populares no caso alemão, relaciona-se a extinguir a dominação estrangeira (no caso a dominação francesa), resolvendo as contradições internas entre elite e povo e construindo uma identidade nacional. Herder, filósofo alemão, critica a ideia de progresso e as concepções evolucionistas, propondo um relativismo histórico. Para o autor as bases da sociedade alemã estão na cultura popular; esta apresentaria três características fundamentais: primitiva, comunitária e pura. Uma primeira separação entre cultura erudita e cultura popular é pensada então sob os termos da autenticidade, do anonimato, do intuitivo, de uma sabedoria popular que não se adquire com o conhecimento formal. Nesse sentido, não é a cultura estritamente das classes populares e subalternas que é enfatizada, mas a idealização de uma cultura através da noção de povo. O entendimento desta cultura popular só é compreensível a partir de uma "substância de cultura" (tradicional) pertencente ao passado. Contudo a transmissão de uma tradição (referendado então no passado) não inibe o desenvolvimento de estilos individuais. Talvez o termo cultura popular, enquanto um conceito residual, só tenha sentido em sociedades de classes. Em sociedades em que exista pouca diferenciação social; no qual o pescador, cantor e curandeiro

\footnotetext{
${ }^{2}$ Assim como cultura popular, povo não é uma categoria homogênea. Para os descobridores da cultura popular o povo eram os camponeses; justamente porque estes representavam os estratos sociais até então pouco afetados pelos processos de industrialização vigentes na Europa Ocidental. Neste sentido, suas canções, danças, contos foram todos adjetivados de populares. Não obstante, este não é um conjunto uniforme e homogêneo, há diferenças de condições sociais e materiais, idade, sexo, religião, educação, dentro deste complexo povo. O Folclore seria assim a ciência que estuda as sobrevivências arcaicas na Idade Moderna destes povos que se acreditava não alterada pela industrialização.
} 
constituem a mesma pessoa, pode-se perceber uma cultura partilhada por todos os membros, o que não quer dizer ausente de interdições.

\section{Folclore e cultura popular}

Distinções de grafia implicam em significações diferentes para o termo folclore. Se grafado com o " $\mathrm{f}$ " minúsculo pode designar, grosso modo, as formas de saber do povo, se grafado com o "F" maiúsculo, refere-se a um saber erudito que estuda aquele saber popular (BRANDÃO, 1984). Contudo os debates que envolvem a palavra folclore tomaram grandes proporções desde a criação do termo por William Thoms, em 1846. O termo nasce no século XIX sob a influência do positivismo e do evolucionismo. Cabia ao Folclore enquanto área do conhecimento, o estudo das sobrevivências, no sentido de que o progresso não abarcaria todos os setores da vida e classes sociais, tendo o "povo" um conhecimento peculiar. Em oposição ao sentido de cultura na França, folclore seria o termo referente à cultura das camadas baixas e subalternas com transmissões orais, ditas tradicionais. Todo este empreendimento de constituição de uma Ciência do Saber Popular era burguês, impregnado das concepções de progresso. O povo seria portador de um saber oral, mecânico em oposição à burguesia culta, das artes. A criação da ideia de folclore é desenvolvida concomitantemente e influenciada pelo pensamento das Ciências Sociais no século XIX.

Neste ínterim, a questão do folclore ao longo do século XX suscitou debates que podem ser resumidos em três grandes perspectivas, como aponta Florestan Fernandes (1989):

a) O folclore como expressão estética da mentalidade popular;

ß) O folclore como disciplina autônoma científica;

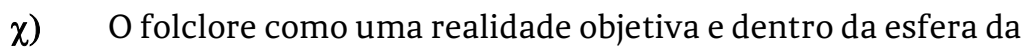
cultura.

O folclore está inserido em uma ordem maior de fenômenos que é a cultura. Portanto, no campo de análise das ciências sociais. Entretanto, vários autores apresentaram posições diferentes. Renato Ortiz destaca um primeiro obstáculo à constituição do Folclore enquanto uma nova disciplina já que seu nome "designa simultaneamente o objeto a ser estudado e a própria ciência" (ORTIZ, 1992, p. 53). Outra questão refere-se à sustentação nas pesquisas dos folcloristas da ideia de anonimato, herança do movimento romântico; bem 
como do esforço colecionador, do cultivo das tradições, numa perspectiva salvacionista e de preservação. A posição de Florestan (1989) é a de que o folclore é um objeto de investigação científica, uma realidade objetiva. Em 1951, acontece no Brasil o I Congresso Brasileiro de Folclore, no qual se define que o Folclore é integrante das ciências antropológicas e culturais (BRANDÃO, 1984).

Os folcloristas, certamente, possuem no Brasil, contribuições teóricas extremamente relevantes para as discussões culturais. Os estudos de Mário de Andrade, que serão detalhados posteriormente, são pioneiros nas pesquisas musicais da chamada cultura popular brasileira. Se um estudioso deseja investigar o folclore em suas relações com as condicionantes culturais e sociais, ele precisará conhecer os métodos das ciências sociais. Parto da perspectiva de que as diferenças dos indivíduos em relação ao acesso à manutenção de determinados conhecimentos estão ligados a questões de classe, raça e gênero e, não de natureza ou mentalidade, como afirmavam os primeiros folcloristas. Estes se preocupavam com as mentalidades dos povos não civilizados, acreditando que estes possuíam uma estrutura mental prélógica. Assim, o folclore era a parte não escrita dos povos civilizados, a sua infância. Esta abordagem era uma necessidade de interesses de classe do século XIX, que promovia uma distinção entre a burguesia e o povo.

\section{Aqueles valores, considerados "sobrevivências", são mais acessíveis a um número maior de indivíduos porque sua transmissão se faz por meio de processos informais, pelo "intercâmbio cotidiano", enquanto a educação sistemática, veículo comum do pensamento científico, abre-se ainda hoje, na maioria dos países, a um número bem mais restrito de pessoas (FERNANDES, 1989, p. 42).}

O folclore, neste ínterim, remete a uma coletivização da criação popular que é altamente dinâmica. Está intimamente ligado a um modo de vida de classe, politicamente ativo, socialmente coletivizado, em constante movimento. Neste aspecto a questão da tradição aparece como fundamental nas relações de transmissão (VANSINA, 2010; HAMPATÉ BA, 2010). A organização não formal dos processos de aprendizagem parece ser o elemento distintivo entre o que é próprio da cultura popular e o que é erudito. Tais distinções também remetem as ideologias do mundo burguês, em que nas sociedades industriais capitalistas o trabalho manual e o trabalho intelectual passam a ser vivenciados como realidades profundamente divergentes. Esta 
dissociação entre o fazer (ligado ao popular) e o saber (erudito) é básico para compreender as relações de conflitos do Capital, a exploração entre seres humanos. A noção de cultura popular, portanto, insere-se no debate sobre hierarquias sociais (CUCHE; 1999). Em uma perspectiva minimalista, a cultura popular seria uma derivação da cultura dominante, uma cultura marginal e alienada. Na perspectiva maximalista, a cultura popular possuiria a criatividade popular, portanto mais autêntica e superior à cultura das elites. No entanto, tais radicalismos não servem nem para fins analíticos. Talvez, uma linha fecunda de análise seja entender as culturas populares por definição enquanto ligadas a grupos subalternos, mas não enquanto tipos ideais com características universais e bem delineadas.

A problemática de se relacionar folclore como sinônimo de cultura popular remete a aspectos conceituais e dos significados históricos (ou construídos historicamente) das palavras. Etimologicamente folclore significa saber popular; a cultura entendida como um saber acumulado geracional implicaria em perceber suas relações sinonímias. Entretanto, o que historicamente ficou compreendido por folclore é uma parcela circunscrita de uma cultura de um povo (um povo fora dos processos de industrialização) com características impostas pelo folclorista como sempre anônimas, tradicionais, autêntica. Enfim, uma visão romântica.

\begin{abstract}
A noção de cultura popular é fruto recente da História; como os antiquários possuíam um mero interesse de colecionador, ela surge somente com o movimento romântico, cristalizando-se com os folcloristas. Trata-se, portanto, de uma criação de intelectuais, que com intenções variadas, voltam-se para a compreensão das tradições (ORTIZ, 1992, p. 61).
\end{abstract}

A construção da ideia de cultura popular acaba por apresentar características bem distintas a depender das relações estabelecidas entre intelectuais e Estado Nacional. Na Inglaterra e França, nota-se uma preocupação "científica" com as questões ligadas aos costumes dos povos. No Sul e Leste Europeus, há um entrelaçamento entre cultura popular e elemento nacional. No Brasil, assim como na Itália e Alemanha, a cultura popular passa a ser pensada pelos intelectuais dos respectivos países como parte da construção do Estado-Nação. A questão inicial dos folcloristas, no sentido de registro das manifestações da cultura popular, está ligada ao projeto moderno dos governos democráticos liberais de manter as concepções 
de povo e nacionalidade dentro do capitalismo. No caso brasileiro, Mário de Andrade é o intelectual representante de um pensamento que valorizava o erudito e o popular. Seus estudos iniciam um novo campo de investigação: a pesquisa do folclore musical. Além de importante figura no delineamento das Políticas Patrimoniais no Brasil.

\section{Mário de andrade e o ensaio sobre a música brasileira}

Para Florestan Fernandes (1989) o conjunto da obra de Mário de Andrade deve ser compreendido a partir da análise dos seus estudos do folclore musical brasileiro. Atualmente as pesquisas relativas às musicalidades tradicionais estão sendo desenvolvidas por pesquisadores de diferentes áreas: História Social, Sociologia, Antropologia, Museologia, Musicologia e a Etnomusicologia. Os estudos referentes ao Samba de Roda, por exemplo, desde a década de 70 estão no âmbito principalmente da Etnomusicologia. Por ser uma disciplina híbrida que abarca tanto conhecimentos musicológicos e etnológicos, permite uma análise profunda das relações entre texto e contexto musical. Entretanto, os primeiros estudos de pesquisa musical no Brasil foram feitos por folcloristas como Silvio Romero, Oneyda Alvarenga e o próprio Mário de Andrade. Dessa forma, a partir de Mário de Andrade e uma breve análise do processo de patrimonialização do Samba de Roda do Recôncavo Baiano, busco dialogar as dimensões entre os aspectos teóricos dos conceitos (culturas populares, folclore, patrimônio) e suas consequências práticas, ou seja, as relações dos intelectuais e suas ideias para conformação de políticas públicas para as culturas populares.

Mário de Andrade concebia a arte erudita e a arte popular em um plano de equilíbrio. Interessante pensar que o termo arte, um elemento de distinção de classe na Europa, é utilizado pelo autor tanto para as manifestações culturais da elite quanto do povo. Para ele estas não podem ser vistas como antagônicas e independentes. É necessária a fusão de ambas para o nascimento de uma terceira arte, verdadeiramente revolucionária e universal. Nota-se um movimento do plano folclórico para o plano da arte erudita. A música popular, acrescida de uma transposição erudita, transformar-se-ia em uma música artística, imediatamente desinteressada. 
No seu Ensaio sobre a Música Brasileira, Mário de Andrade (1962) busca caracterizar esta música brasileira em suas influências e complexidades. Uma questão central é a análise do ritmo. O autor percebe as diferenças rítmicas entre a música inscrita nas pautas e a obra executada, ressaltando que muitas vezes ambas diferem totalmente. Sua explicação é a de que existe uma síntese que os compositores populares apresentam aos pesquisadores que se propõem escrever as pautas. Porém a música popular tem a marca da improvisação, das composições instantâneas, que ao mesmo tempo a torna complexa e fugidia para um conhecimento científico que não se propõe pensar a mudança.

Para além das influências diretas na música brasileira (indígena, africana e portuguesa), Mário de Andrade destaca a espanhola e hispanoamericana, como a habanera e o tango, o jazz estadunidense e outras referências europeias como a valsa, polca, mazurca, shottsh. Em relação à melodia da música popular, Mário de Andrade a adjetiva como dinamogênica, ou seja, é voltada às necessidades humanas inconscientes (para o autor a arte nacional está ligada aos processos inconscientes do povo, no sentido que não existe um empreendimento claro, um objetivo específico, neste sentido seria uma arte eminentemente desinteressada), se dissocia paulatinamente de perspectivas individualistas para incorporar valores gerais, tornando-se pública.

Mário de Andrade, ao passo que valoriza o elemento popular não deixa de perscrutar um aprimoramento da música popular através da música erudita. Assim, compositores como Villa-Lobos e Ernesto Nazareth representariam esse processo de refinamento, quando a música popular é submetida à manipulação erudita de um corpo de profissionais (BOURDIEU, 2009). O autor de Macunaíma parece defender a apropriação erudita dos temas populares para a criação de uma arte original.

A pesquisa sobre uma determinada música popular é sempre um desafio e requer atualizações constantes. Por ser extremamente dinâmica, a tentativa de colocar em pautas seus sons musicais, traz uma série de dificuldades. São necessários novos desdobramentos epistemológicos para perceber este processo recorrente de significações. A música popular, apesar da complexa rede de ressignificações, mantém características tradicionais (no sentido mutável, trazendo uma ideia de representatividade) que atribui uma identidade social de pertencimento a um determinado grupo, ao mesmo 
tempo, que estabelece uma ponte simbólica entre o passado e o presente que constantemente se reconfigura.

\section{Política patrimonial e culturas populares}

No Brasil, a inserção da noção de patrimônio delineia-se no início do século $\mathrm{XX}$, conjugando esforços para a construção da identidade nacional somada a valorização de determinados símbolos, que foram deslocados de sua acepção e significados locais, enquanto pertencentes à cultura popular, para um plano político de construção da nação, enquanto ideologia (ORTIZ, 2006). A partir de 1920, dois eventos contribuíram para o direcionamento político desta ideia de patrimônio: o movimento modernista e a instauração do Estado Novo. A temática do patrimônio volta-se, enquanto expressão da modernidade, para uma autonomia da esfera cultural, destacando o caráter “autêntico" das expressões artísticas do país. Mário de Andrade é uma figura central em todo esse processo, tendo contribuído ativamente na criação do Serviço do Patrimônio Histórico e Artístico Nacional (FONSECA, 2009).

Para os modernistas, as tradições do povo brasileiro, ou melhor, de acordo com uma ideia do que seria o povo, era a chave para a identidade nacional e imprimiam um valor universal ao país diante do mundo (CAVALCANTI, 1990). Não obstante alegava-se a importância das manifestações populares, sob a valorização de uma abstrata cultura popular que se sobrepunha ao próprio povo portador dela. Uma das consequências, senão a principal, é a de que todo o passado escravocrata de genocídio negro/indígena e todas as relações racistas presentes foram invisibilizados.

A análise discutida a partir de Mário de Andrade insere-se na perspectiva de pensar a música sob a ótica dos estudos folcloristas. E também como essas noções de cultura popular, povo e patrimônio, construídas pelos intelectuais brasileiros, foram moldando a forma como o Estado se relaciona com tais manifestações adjetivadas de populares. Desde o Museu Histórico e Nacional (1922), passando pelo Serviço do Patrimônio Histórico e Artístico Nacional (1937), a Fundação Nacional Pró-Memória (anos 1960 a 1980), o Instituto Brasileiro do Patrimônio Cultural (anos 1980 e 1990) até chegar ao Instituto do Patrimônio Histórico e Artístico Nacional, nos anos 1990, o conceito de patrimônio atrelava-se ao plano material, com políticas de tombamento (GONÇALVES, 1996; FONSECA, 2001). Nos anos 2000, com a 
instituição do Registro de Bens Culturais de Natureza Imaterial, é que os aspectos intangíveis do patrimônio passariam também a ser foco de políticas públicas.

O Samba de Roda do Recôncavo Baiano insere-se neste novo momento da Política Patrimonial, passando pelo processo de patrimonialização nos anos de 2004 (Patrimônio Imaterial do Brasil) e 2005 (Patrimônio Oral da Humanidade). Desde então outras musicalidades também foram outorgadas com o título de Patrimônio Cultural do Brasil. O “Jongo no Sudeste" foi registrado em 2005 e suas práticas são destacadas nos quintais das periferias urbanas e comunidades rurais do Sudeste brasileiro. Também em 2005, foi patrimonializado o "Modo de Fazer Viola de Cocho" como um modo de saber-fazer presente na região Centro-Oeste do Brasil. Em 2006 foi produzido o dossiê “Matrizes do Samba no Rio de Janeiro", tendo como lócus principal a referida cidade e todo o processo de marginalização do samba até sua transformação em símbolo nacional. O Carimbó recebeu o título de Patrimônio Imaterial Brasileiro em 2014, referendado a partir do estado do Pará.

O Samba de Roda tem sido objeto de estudo dentro da academia, sobretudo a partir de uma perspectiva etnomusicológica. Trabalhos como de Ralph Waddey (1980, 1981), Thiago de Oliveira Pinto (1991), Katharina Döring (2002), Francisca Marques (2003), Cassio Nobre (2008), Raiana Alves (2009) entre outros, fazem uma importante abordagem sobre esta musicalidade. Tais pesquisas trazem contribuições significativas de levantamento histórico e diferentes práticas etnográficas envolvendo os sambas. O próprio Dossiê Samba de Roda do Recôncavo Baiano, também foi organizado por um etnomusicólogo, Carlos Sandroni (2007). Rívia Alencar (2010) analisa a patrimonialização enquanto um ritual, estabelecendo conexões entre o Estado e os sambadores. Estudos como os de Michael Iyanaga (2011) e Nina Graeff (2013), ainda sob a perspectiva etnomusicológica, versam sobre o samba de caruru e as performances no samba de roda. Tais contribuições são importantes para atestar a pluralidade de tradições que envolvem os Sambas de Roda no estado da Bahia.

Katharina Döring (2016) em um livro recente, Cantador de Chula: o samba antigo do Recôncavo baiano, sintetizando mais de 15 anos de pesquisa, fez um estudo dos sambas chulas em específico, porém indicando vários caminhos para uma abordagem crítica das musicalidades negras na Bahia. 
Interessante notar que o Recôncavo baiano como universo empírico de sua pesquisa não é aquele do discurso oficial, mas sim um espaço complexo, "de milhares de meandros e desdobramentos geo-culturais, socioeconômicos e valores espirituais" (DÖRING, 2016, p. 12).

Cada vez mais o reconhecimento do Patrimônio Imaterial de manifestações culturais afro-brasileiras é uma realidade. A partir de uma política além do tombamento de "pedra e cal" e uma intensa luta do movimento negro em meados do século XX até os dias atuais, na esfera cultural cada vez mais existe o reconhecimento histórico e de valorização da herança cultural negra no Brasil. Entretanto, este não é um processo isento de contradições. Santos (2005), ao analisar a democracia racial enquanto mito (relacionando esse pensamento mítico a uma ideologia política) evidencia o binômio Poder/Cultura nos discursos oficiais. O mesmo Estado que incentivava a produção cultural negra na Bahia e que se apropriava dos elementos enquanto símbolos nacionais, por exemplo, era também o agente da repressão do corpo negro visto como subversivo. Na ditadura militar, o mesmo governo que incentivava a produção de símbolos nacionais, era o promotor da censura e repressão.

No estado da Bahia, nos anos de 1960 e 1970, a Fundação do Patrimônio Artístico e Cultural da Bahia e o Programa de Estudos das Potencialidades do Patrimônio Artístico e Cultural Baiano (PROPREPAC) eram instituições através das quais o Estado brasileiro pretendia desenvolver o turismo cultural. Assim "as ações culturais estatais possuíam um peso político e econômico. Não visavam simplesmente reconhecer a contribuição e a existência de manifestações afro-brasileiras" (SANTOS, 2005, p. 114).

O Samba de Roda do Recôncavo Baiano insere-se nessa apropriação de uma herança cultural negra pelo Estado brasileiro. Não se trata apenas da espetacularização das culturas populares e das relações entre patrimônio e a indústria do entretenimento, que obviamente possui uma dimensão fundamental nesse processo. Para além do discurso oficial de valorização de um bem patrimonializado, existem demandas econômicas e políticas que são diluídas, muitas vezes ocultadas, através de uma retórica política que evidencia e reitera a importância da preservação da diversidade cultural como sinônimo de valorização destas culturas ditas tradicionais. 
Contudo, a valorização destas manifestações afro-brasileiras via Política Patrimonial não anula os processos de desigualdade social da sociedade capitalista. Para Carvalho (2004), o tempo seria um dos maiores patrimônios culturais intangíveis das comunidades indígenas e afrobrasileiras. Se no contexto das comunidades os sambas possuem uma lógica de duração de horas, muitas vezes até de dias; nas apresentações destinadas a uma classe média urbana o "tempo é roubado" em função do enquadramento das mesmas em um instante temporal de duas horas, por exemplo. As dinâmicas de sociabilidades e ritualização dos seus valores são espoliados. Como aponta Carvalho: "o que aparece para o consumidor como canto, dança, poesia e drama tradicional afro-brasileiro é de fato um simulacro natimorto que assombra como um fantasma do mundo maquínico da produção capitalista" (CARVALHO, 2004, p. 8). Por outro lado, a valorização do bem cultural (agora patrimonializado, apropriado e expropriado pela indústria de entretenimento) em detrimento das comunidades portadoras desses saberesfazeres é um espólio do ponto de vista econômico. Ocorre uma apropriação e valorização (comercial) destes bens, mas as situações de desigualdades sociais e raciais são mantidas. A política patrimonial certamente não cria esta espetacularização das culturas, mas ao dialogar a partir da diversidade cultural e, como um novo elemento de venda para o consumo do turismo cultural, ajuda a exponenciar este quadro.

Além dessa dimensão política, que é fundamental para entender o momento atual dos grupos, tal musicalidade possui também uma profundidade histórica em função de sua pluralidade de tradições, bem como do seu caráter afro-brasileiro. A fala, a oralidade, as musicalidades, as expressões do corpo são elementos fundamentais nas manifestações culturais afro-brasileiras. Sob as condições de escravidão no "Novo Mundo", toda essa dimensão simbólica tornou-se mecanismo de resistência. Para além do sofrimento e dessa experiência traumática (na ausência de uma palavra que consiga descrever psicologicamente o que deve ter sido a escravidão), tais elementos simbólicos, e a música incluída nesse processo, foram fundamentais para formar grupos de resistência e também criar laços de solidariedade tão importantes se atentarmos para a dimensão do cotidiano (LIMA, 2017).

Os Sambas de Roda envolvem toda uma poética dos sons e versos. Toda uma coreografia, dança e uso do corpo. O corpo que dança, o corpo que 
toca, o corpo que canta, o corpo que também é instrumento. A roda é ordem, é aprendizagem, é uma pedagogia. Os sambas também são brincadeiras, criam redes de solidariedade, fazem parte do trabalho no campo ou festividades citadinas. No contexto político dos sambas de roda, o uso dos termos tradição e cultura popular são reatualizados e tornam-se categorias êmicas. Por exemplo, sambadores e sambadeiras falam em tradições do Samba de Roda para atestar as especificidades que a musicalidade possui em cada região. Assim a ideia de tradicional já é um reflexo da ideologia da modernidade. Já a palavra folclore, em minhas pesquisas, não é acionada de forma significativa.

Todavia, quando estas relações complexas são desenvolvidas na Política Cultural, as concepções de patrimônio, mesmo esta que destaca a imaterialidade, aplicadas ao universo das culturas populares parecem reafirmar na prática aquelas noções de autenticidade e tradicionalidades cunhadas no século XIX e instituídas no Brasil pelos folcloristas (VILHENA, 1992).

A regulação da cultura pelo Estado, no caso do Patrimônio Cultural, sinaliza então o debate sobre o lugar do conhecimento tradicional na política. Para Manuela Carneiro da Cunha (2009), o conhecimento tradicional não necessariamente está ligado a tempos antigos imemoriais e, sim, a um conjunto duradouro de procedimentos diversos que geram conhecimentos. Os regimes de conhecimento podem ser pautados na experiência direta ou no reconhecimento de fontes. Obviamente não excluindo outros procedimentos possíveis, fiquemos nestes dois exemplos que a autora destaca. Acredito que ambos procedimentos podem ser identificados nos sambas de roda. Para conferir autoridade, as fontes nos sambas de roda remetem a sambadores e sambadeiras que possuem ampla vivência e memória nos sambas de determinada região. Pela importância da transmissão oral, o conhecimento de diversos cânticos e também as práticas antigas dos sambas denotam uma fonte de autoridade que é imediatamente respeitada.

Outro ponto de partida para compreender tais noções de tradição, popular, autenticidade, seria perceber as mudanças, engendradas pelo desenvolvimento do capitalismo, na cultura dos trabalhadores. A associação equívoca com a concepção de tradição no sentido conservador pode estar ligada à ideia de luta e resistência no quadro mais amplo de apropriação e expropriação do trabalho. Ou seja, em uma dialética de contenção e 
resistência, a cultura dominante desorganiza e reorganiza constantemente a cultura popular (isto não quer dizer que os grupos não possuam agência sobre suas produções culturais, o que se está evidenciando são as lutas de classes). Tal cultura dominante não é somente a figura mítica do burguês que desconfigura (no processo de alienação) culturalmente o trabalhador, mas também se manifesta em várias instâncias do governo e na própria academia. Os processos de patrimonialização, por exemplo, é um aspecto claro desta problemática, em que intelectuais e burocratas possuem o poder discursivo e prático de (des)(re)organizar as culturas populares ${ }^{3}$. Tendo em vista estes movimentos dialéticos e a própria heterogeneidade do conceito, as culturas populares podem ser entendidas como:

[...] as formas e atividades cujas raízes se situam nas condições sociais e materiais de classes específicas; que estive ram incorporadas nas tradições e práticas populares [...] numa tensão contínua (de relacionamento, influência e antagonismo) com a cultura dominante [...]. Seu principal foco de atenção é a relação entre a cultura e as questões de hegemonia (HALL, 2003, p. 241).

As questões de hegemonia são melhores compreendidas se analisadas como se dão as relações entre Estado e culturas populares no Brasil. O Samba de Roda, ao ser patrimonializado, está posto implicitamente na sua salvaguarda a ideia de resgate e preservação deste conhecimento tradicional. A problemática é que a Política do Patrimônio trata este conhecimento tradicional:

[...] como um conjunto completo e fechado de lendas e sabedorias transmitidas desde tempos imemoriais e detidas por certas populações humanas, um conjunto de saberes preservados (mas não enriquecidos) pelas gerações atuais. Note-se que uma concepção como esta enviesa as políticas públicas na direção do "salvamento". O que passa a importar não é a conservação dos modos de produção dos conhecimentos tradicionais, e sim o resgate e a preservação (CUNHA, 2009, p. 364).

A ênfase na ressalva entre parênteses - "mas não enriquecidos" pode ser identificada na política ao determinar, por exemplo, os processos de

\footnotetext{
${ }^{3}$ Para um maior aprofundamento dessas relações entre Política Patrimonial e Culturas Populares, a partir do processo de patrimonialização do Samba de Roda, ver o trabalho "Nas Margens dos Sambas: um estudo sobre a Ideologia do Patrimônio" (BERNARDES, 2016).
} 
revalidação do título patrimonial a cada 10 anos. O que está posto não são os regimes de conhecimento, mas o que importa na política pública é a preservação do conhecimento tal como foi cristalizado no discurso oficial. A Salvaguarda enfatiza a preservação de saberes fazeres sem identificar regimes de procedimentos que tornam o conhecimento tradicional vivo, dinâmico e sempre atualizado, ou seja, que seria justamente enriquecido pelas gerações atuais.

\section{Considerações finais}

A temática do Patrimônio Cultural mostra-se, de certa forma, como um "empreendimento folclórico" do século XXI. Obviamente com avanços conceituais e políticos fundamentais para a valorização de grupos subalternos, que através da política pública, encontram meios de empoderamento e protagonismo. Contudo também há continuidades de uma visão que ainda persiste e encontra suas bases no olhar folclorista que busca catalogar, preservar, conservar, cristalizar.

A síntese desse debate se desdobra em uma pergunta: por que o “governo da cultura" é importante? Stuart Hall (1997) indica duas respostas. Primeiro que a cultura é uma área-chave de mudança e debate nas sociedades contemporâneas. Segundo, que a cultura nos governa. As práticas sociais, dessa forma, são condicionadas pelo viés cultural ou discurso de existência. Não é que a cultura, em termos substantivos, ou seja, o seu lugar na estrutura empírica real, seja algo absoluto. Mas toda prática social é dependente e possui relações com o significado, tem seu caráter discursivo.

Desta forma não pontuo respostas. Busquei apenas, de uma forma dialógica, sinalizar que as construções teóricas possuem uma materialidade. Indicando como categorias forjadas no século XIX, e o seu ulterior desenvolvimento histórico, demandam uma atualidade política. As relações entre folcloristas e a Política Patrimonial no Brasil foram pensadas aqui através de Mário de Andrade e do universo musical dos sambas de roda, como um exemplo empírico dos usos políticos dos conceitos de cultura popular e folclore, e também no atual conceito de patrimônio cultural tão devedor daqueles.

Para entender o palco de disputa em que estas categorias são acionadas, é fundamental compreender a sua história enquanto conceitos. As 
ideias são forjadas e utilizadas por intelectuais que ocupam uma determinada posição social e, quando passam para o plano do Estado, possuem uma implicação prática de influência no cotidiano das pessoas. As notas históricas e políticas do conceito de culturas populares, assim se entrelaçam a outras noções como a de folclore, povo e patrimônio. Dessa forma adquirem uma materialidade substantiva, na medida em que direcionam o conteúdo e a forma como as políticas públicas (no caso aqui em específico, as políticas culturais) são aplicadas.

\section{Referências}

ALENCAR, Rívia R. B. O Samba de Roda na Gira do Patrimônio. Tese (Doutorado). Departamento de Antropologia Social, UNICAMP, 2010.

ALVES, Raiana. A política de salvaguarda do patrimônio imaterial e os seus impactos no samba de roda do recôncavo baiano. Dissertação (Mestrado). Departamento de Etnomusicologia, UFBA, 2009.

ANDRADE, Mário. Ensaio sobre a Música Brasileira. São Paulo: Livraria Martins Editora, 1962.

BERNARDES, Marcus. Nas Margens dos Sambas: um estudo sobre a Ideologia do Patrimônio. Goiânia: UFG. Programa de Pós-Graduação em Antropologia Social. Dissertação de Mestrado, 2016.

BRANDÃO, Carlos Rodrigues. O que é folclore. São Paulo: Editora Brasiliense, 1984.

BOURDIEU, Pierre. A economia das trocas simbólicas. São Paulo: Perspectivas, 2009.

BURKE, Peter. Variedades de história cultural. Tradução Alda Porto. Rio de Janeiro: Civilização Brasileira; 2. ed, 2006.

BURKE, Peter. Cultura Popular na Idade Moderna. São Paulo: Companhia das Letras, 2010.

CARVALHO, José Jorge. Metamorfoses das tradições performáticas afrobrasileiras: de patrimônio cultural a indústria de entretenimento. UnB, Série antropologia, n. 354, 2004.

CASCUDO, Luís da Câmara. Dicionário do Folclore Brasileiro. São Paulo: Ediouro, 1998. 
CAVALCANTI, Maria Laura. Traçando Fronteiras: Florestan Fernandes e Marginalização do Folclore. Rio de Janeiro: Estudos Históricos, vol. 3, n. 5, 1990, p. 75-92.

CUCHE, Denys. A noção de cultura nas ciências sociais. Bauru: EDUSC, 1999.

CUNHA, Manuela Carneiro da. Cultura com Aspas e outros ensaios. São Paulo: Cosac Naify, 2009.

DÖRING, Katharina. O samba de roda do Sembagota: Tradição e contemporaneidade. Dissertação de mestrado, UFBA, 2002.

DÖRING, Katharina. O samba da Bahia: Tradição pouca conhecida. ICTUS, 5:69-92, 2004.

DÖRING, Katharina. Cantado de Chula: o samba antigo do Recôncavo baiano. Salvador: Pinaúna, 2016.

ELIAS, Norbert. O Processo Civilizador, volume I: uma história dos costumes. Rio de Janeiro: Zahar, 2011.

ELIAS, Norbert. Teoria Simbólica. Portugal: Celta Editora, 2002.

FERNANDES, Florestan. O Folclore em questão. São Paulo: Editora Hucitec, 1989.

FONSECA, Maria Cecília L. Para além da pedra e cal. Rio de Janeiro: Revista Tempo Brasileiro, v.1, n. 147, 2001.

FONSECA, Maria Cecília L. O Patrimônio em Processo: trajetória da política federal de preservação no Brasil. Rio de Janeiro: Editora UFRJ, 2009.

GRAEFF, Nina. Samba de Roda: comemorando identidades afro-brasileiras através da performance musical. Artelogie, n. 4, pp. xx-xx, 2013. Dossier "Fêtes et célébrations en Amérique Latine": estética como eixo transversal, em abordagens políticas, antropológicas e histórica.

HALBWACHS, Maurice. A Memória Coletiva. São Paulo: Editora Vértice, 1990.

GONÇALVES, José Reginaldo Santos. A Retórica da Perda: os discursos do patrimônio cultural no Brasil. Rio de Janeiro, Ed. UFRJ/IPHAN, 1996.

HALL, Stuart. A centralidade da cultura: notas sobre as revoluções culturais do nosso tempo. Educação \& Realidade. Porto Alegre, v. 22, n. 2, jul./dez. 1997, p. 15-46. 
HALL, Stuart. Da Diáspora: Identidades e mediações culturais. Belo Horizonte: Editora UFMG, 2003.

HAMPATÉ BA, A. A tradição viva. IN: Ki-Zerbo, Joseph (Editor). História geral da África I: Metodologia e pré-história da África. Brasília: UNESCO, 2010, p. 167-212.

HOBSBAWM, Eric; RANGER, Terence (Org.). A Invenção das Tradições. Rio de Janeiro: Paz e Terra, 1997.

IYANAGA, Michael. O samba de caruru da Bahia: tradição pouco conhecida. ICTUS, 11-2, 2011.

IPHAN. Samba de Roda do Recôncavo Baiano. Dossiê IPHAN 4: Ministério da Cultura, 2007.

LIMA, Ari. O que fazer com o cabelo de Marly? Estudos sobre as relações raciais e música negra. Salvador: Eduneb, 2017.

LIMA FILHO, M. F.; BELTRÃO, J. F.; ECKERT, C. Antropologia e patrimônio cultural: diálogos e desafios contemporâneos. Blumenau: Nova Letra, 2007.

MARQUES, Francisca. Samba de roda em Cachoeira, Bahia: Uma abordagem etnomusicológica. Dissertação (Mestrado). Departamento de Etnomusicologia, UFRJ, 2003.

NOBRE, Cassio. Violas nos sambas do Recôncavo Baiano. Dissertação de mestrado, UFBA, 2008.

OLIVEIRA PINTO, Tiago. Capoeira, Samba, Candomblé. Afro-brasilianische Musik im Recôncavo, Bahia. Berlim: Staatliche Museen / Preussischer Kulturbesitz, 1991.

ORTIZ, Renato. Cultura brasileira e Identidade nacional. São Paulo: Brasiliense, 2006.

ORTIZ, Renato. Cultura Popular: Românticos e Folcloristas. São Paulo: Edito Olho d'Água, 1992.

ORTIZ, Renato. Mundialização e Cultura. São Paulo: Brasiliense, 2006.

SANSONE, Livio; SANTOS, Jocélio Teles dos (Org.). Ritmos em trânsito: sócioantropologia da música baiana. São Paulo: Dynamis Editorial; Salvador: Programa A Cor da Bahia e Projeto S.A.M.B.A., 1997.

SANTOS, Jocélio Teles. $O$ poder da cultura e a cultura no poder: a disputa simbólica da herança cultural negra no Brasil. Salvador: EDUFBA, 2005. 
TINHORÃO, José Ramos. Cultura Popular: temas e questões. São Paulo: Ed. 34, 2001.

VANSINA, I. A tradição oral e sua metodologia. IN: Ki-Zerbo, Joseph (Editor). História geral da África I: Metodologia e pré-história da África. Brasília: UNESCO, p. 139-166, 2010.

VILHENA, Luís Rodolfo. Os estudos de folclore: os impasses na constituição de uma ciência brasileira. Rio de Janeiro: Ciências Sociais Hoje, ANPOCS, 1992.

WADDEY, Ralph Cole. 'Viola de Samba' and 'Samba de Viola' in the Recôncavo of Bahia (Brazil). Latin American Music Review, vol. 1, n. 2, p. 196- 212, 1980.

WADDEY, Ralph Cole. 'Viola de Samba' and 'Samba de Viola' in the Recôncavo of Bahia (Brazil) Part II: 'Samba de Viola'. Latin American Music Review, v. 2, n. 2, p. 252-279, 1981.

Recebido em: 31/10/2018

Aprovado em: 04/12/2018 